\title{
ANALISIS SISTEM PENGENDALIAN INTERNAL (SPI) TERHADAP SISTEM AKUNTANSI PEMBERIAN KREDIT MODAL KERJA PADA PT. BANK SULUTGO CABANG PEMBANTU SAM RATULANGI
}

\author{
Margareth Sondakh ${ }^{1}$, Ventje Ilat ${ }^{2}$, Novi S. Budiarso ${ }^{3}$ \\ 1,2,3 Jurusan Akuntansi, Fakultas Ekonomi dan Bisnis, Universitas Sam Ratulangi, Jl. Kampus Bahu, Manado, \\ 95115, Indonesia \\ E-mail: rillysondakh15@gmail.com
}

\begin{abstract}
In carrying out a credit product, especially working capital credit at a particular bank, there is an accounting system used to process data so that it can obtain financial information needed by the parties concerned. Therefore, to minimize the occurrence of errors and fraud in an accounting system for working capital credit, a good and adequate internal control system is needed. The internal control system is a system that greatly influences the success of the company in carrying out its policies. Therefore, it is necessary to have a system of internal control, especially with respect to the accounting system in providing working capital loans to reduce fraud that will result in losses to the company. This study aims to analyze how the internal control system of the accounting system in providing working capital loans at PT. Bank SulutGo especially in the Sam Ratulangi support branch. The method used is descriptive qualitative. And the results show that PT. Bank SulutGo's Sam Ratulangi subsidiary branch has implemented internal control components well and adequately. And supported by policies and procedures for providing good working capital loans that are also applied by the company.
\end{abstract}

Keywords: Accounting system, internal control system, and working capital credit.

\section{PENDAHULUAN}

Perbankan mempunyai peranan yang sangat penting untuk memajukan perekonomian dalam suatu negara termasuk Indonesia. Hampir semua pribadi/perorangan dan lembaga baik sosial maupun perusahaan yang berhubungan dengan kegiatan keuangan selalu membutuhkan jasa dari perbankan. Perbankan yang adalah salah satu lembaga keuangan yang memiliki kegiatan pokok yaitu untuk menghimpun dana dari masyarakat dan kemudian dana tersebut disalurkan kembali kepada masyarakat melalui pemberian pinjaman atau kredit. Istilah kredit berasal dari bahasa Yunani, yaitu credere yang artinya kepercayaan. Arti dari kata tersebut menunjukan bahwa dasar dari pemberian kredit adalah kepercayaan. Hal ini berarti bahwa pemberi kredit (kreditur) percaya bahwa penerima kredit (debitur) akan sanggup untuk memenuhi segala sesuatu yang telah menjadi perjanjian di antara kedua belah pihak.

Menurut Kamus Besar Bahasa Indonesia (KBBI) kredit artinya pinjaman uang dengan pembayaran atau pengembaliannya secara mengangsur. Dan menurut Kasmir (2012:72) kredit artinya mendapatkan barang atau meminjam uang dan membayar atau mengembalikan dengan cara menyicil atau mengangsur dikemudian hari sesuai dengan perjanjian.

Dalam kegiatan pokok perbankan yaitu penyaluran dana kepada masyarakat. Lebih khususnya melalui kredit terdapat juga suatu produk yaitu kredit modal kerja. Yang memerlukan sistem pengendalian internal terhadap sistem akuntansi untuk mendukung bank dalam mencapai tujuan dan meminimalisir terjadinya risiko. Menurut Budisantoso dan Nuritomo (2014:149) Kredit Modal Kerja (KMK) adalah pembiayaan kebutuhan untuk modal kerja dari nasabah dengan memberikan kredit. Dan definisi sistem pengendalian internal itu adalah usaha yang dilakukan oleh suatu entitas agar bisa mencapai tujuan dan mendorong 
efisiensi serta untuk mematuhi aturan yang ditetapkan oleh manajemen. Untuk definisi sistem akuntansi adalah suatu sistem yang terdiri dari beberapa unsur yang saling berkaitan sehingga dapat berguna untuk mengelolah data dari suatu entitas.

PT. Bank SulutGo Cabang Pembantu Sam Ratulangi adalah salah satu bank yang menyediakan produk layanan kredit khususnya kredit modal kerja bagi debitur. Dengan cara memenuhi syarat dan ketentuan yang berlaku pada saat permohonan kredit. Dan proses permohonan tersebut dapat dilakukan secara cepat, sehingga memungkinkan untuk timbulnya kurang efektif dalam melakukan kegiatan analisis kredit yang berlangsung. Memungkinkan juga untuk terjadinya kesalahan dalam proses pemberian kredit atau pengawasan kredit kepada debitur, yang mengakibatkan terjadinya kredit bermasalah atau kredit macet. Dan dari data yang diperoleh mengenai tingkat Non Performing Loan (NPL) pada PT. Bank SulutGo Cabang Pembantu Sam Ratulangi periode akhir 2015-September 2017 mengalami kenaikan dari $0.94 \%$ menjadi $1.33 \%$ artinya $0,39 \%$ besarnya kenaikan yang terjadi dan mengalami penurunan kembali pada periode akhir 2016-September 2017 dari $0.68 \%$ menjadi $0.54 \%$. Hal itu berarti telah terjadi penurunan sebesar 0.14\%. Meskipun Non Performing Loan (NPL) pada Bank SulutGo Cabang Pembantu Sam Ratulangi telah mengalami penurunan namun berdasarkan data tersebut dapat dilihat bahwa masih terjadi kredit macet/NPL pada Bank SulutGo Cabang Pembantu Sam Ratulangi.

\section{TINJAUAN PUSTAKA}

Akuntansi, Sistem, dan Sistem Akuntansi. Menurut Pontoh (2013:2) akuntansi adalah sebuah informasi yang dihasilkan oleh perusahaan dari sistem akuntansi dan digunakan untuk mengambil keputusan atau untuk masyarakat umum. Dan Mulyadi (2016:5) mendefiniskan sistem sebagai suatu jaringan prosedur yang dibuat sesuai pola yang terpadu untuk melaksanakan kegiatan-kegiatan pokok dari perusahaan. Baridwan (2012:4) menyatakan bahwa sistem akuntansi adalah pengelolaan data dari suatu usaha yang terdiri formulir, catatan, prosedur serta alat dan bertujuan untuk membuat laporan yang dibutuhkan oleh manajemen dalam mengawasi usaha dan untuk pihak eksternal yang berkepentingan.

Tujuan Sistem Akuntansi. Adapun tujuan sistem akuntansi menurut Mulyadi (2016:15) yaitu sebagai berikut:

1. Untuk memberikan informasi bagi pengelolah usaha.

2. Untuk mengubah hasil informasi dari sebuah sistem yang sudah ada menjadi lebih baik, mulai dari mutu, penyajian yang tepat, serta struktur informasinya.

3. Untuk mengubah pengendalian akuntansi dan pengecekan internal menjadi lebih baik atau untuk memperbaiki keandalan informasi akuntansi dan untuk menyediakan catatan mengenai pertanggungjawaban serta perlindungan kekayaan.

4. Untuk mengurangi biaya klerikal dalam penyelenggaraan catatan akuntansi.

Unsur-Unsur Sistem Akuntansi. Unsur sistem akuntansi menurut Mulyadi (2016:3) yaitu:

1. Fomulir berupa dokumen yang berisi semua transaksi yang terjadi.

2. Jurnal yang merupakan proses awal dari pencatatan akuntansi yang berguna untuk mencatat, mengelompokkan, dan membuat ringkasan dari data-data yang ada.

3. Buku besar yang memuat akun-akun guna untuk membuat ringkasan dari data-data keuangan yang telah dicatat pada jurnal sebelumnnya.

4. Buku besar pembantu yang memuat akun-akun tertentu yang lebih rinci mengenai data keuangan yang ada didalam buku besar,

5. Laporan keuangan adalah hasil akhir dari proses pencatan akuntansi yang terdiri dari laporan posisi keuangan, laporan laba rugi, laporan perubahan modal, laporan harga pokok produksi, laporan beban pemasaran, dan semua laporan yang berisi informasi keluaran (output) dari sistem akuntansi. 
Pengendalian Internal dan Sistem Pengendalian Internal. Menurut Committee of Sponsoring Organizaation (COSO) Framework yang dirilis tahun 2013 pengertian pengendalian internal adalah pencapaian tujuan atas operasi, pelaporan, dan kepatuhan yang dipengaruhi oleh pihak internal perusahaan. Dan sistem pengendalian internal menurut Mulyadi (2016:129) adalah suatu sistem yang dikoordinasikan untuk menjaga semua kepemilikan entitas, untuk meneliti data akuntansi, mendorong untuk mematuhi aturan manajemen, serta efisiensi. Sedangkan menurut Krismiaji (2015:218) sistem pengendalian internal adalah proses perencanaan organisasi dan penggunaan metode yang akan berguna untuk menjaga aset, memberikan informasi akurat, mendorong efisiensi, serta dipatuhinya setiap aturan yang telah ditetapkan.

Tujuan Sistem Pengendalian Internal. Menurut Mulyadi (2016: 129) tujuan sistem pengendalian internal adalah untuk menlindungi aktiva organisasi, mengecek ketelitian dan keandalan organisasi, mendorong dipatuhinya aturan yang telah ditetapkan manajemen dan efisiensi entitas. Dan menurut Walter (2012: 233) sistem pengendalian internal bertujuan untuk melindungi aset, mendorong karyawan untuk menaati aturan perusahaan, mendorong efisiensi operasional, memastikan catatan akuntansi yang akurat dan dapat dipercaya, serta untuk mematuhi hukum yang ada.

Komponen Sistem Pengendalian Internal Menurut Standard Committee of Sponsoring Organizaation (COSO) Framework yang dirilis tahun 2013

1. Lingkungan pengendalian adalah komponen yang paling penting dari komponen yang lainnya karena akan menuntut setiap individu dalam sebuah perusahaan untuk berintegritas, bertanggungjawab, dan memiliki nilai-nilai etis serta berkompetisi dilingkungan perusahaan tersebut. Berikut ini adalah unsur-unsur yang termasuk dalam komponen lingkungan pengendalian seperti:

a. Berkomitmen terhadap integritas serta nilai etis.

b. Melakukan tanggungjawab pengawasan.

c. Menetapkan struktur, wewenang dan tanggungjawab.

d. Menunjukkan komitmen terhadap kompetisi.

e. Mendorong akuntabilitas

2. Penlaian risiko yaitu setiap organisasi harus waspada berhubungan dengan risiko yang akan dihadapi. Dan harus terintegrasi dengan penjualan, produksi, pemasaran, keuangan serta kegiatan lainnya sehingga organisasi bisa beroperasi secara harmonis. Organisasi juga harus menetapkan mekanisme untuk mengidentifikasi, menganalisis dan mengelola risiko tersebut. Dalam organisasi, penilaian risiko terkait dengan kemampuan mengidentifikasi serta mengukur besarnya risiko dalam mencapai tujuan organisasi. Kemampuan setiap anggota organisasi untuk menilai risiko, akan tinggi dalam lingkungan pengendalian internal yang baik begitupun sebaliknya. Dalam lingkungan pengendalian internal yang buruk, kemampuan anggota organisasi untuk penilaian risiko akan sangat rendah. Berikut ini adalah unsur-unsur dalam komponen penilaian:

a. Menentukan tujuan yang sesuai.

b. Mengidentifikasi dan menganalisis risiko.

c. Menilai risiko fraud.

d. Mengidentifikasi dan menganalisis perubahan yang signifikan.

3. Aktivitas pengendalian dalam hal ini merupakan sebuah aktivitas yang dilakukan oleh perusahaan untuk mengidentifikasikan setiap risiko dalam mencapai tujuan. Unsur-unsur yang akan mendorong aktivitas pengendalian adalah:

a. Memilih dan mengembangkan kegiatan pengendalian.

b. Memilih dan mengembangkan kontrol umum atas teknologi.

c. Merinci ke dalam kebijakan dan prosedur. 
4. Sistem informasi dan komunikasi adalah komponen pendukung dari komponen lainnya. Dimana dengan adanya sistem informasi dan komunikasi maka akan memudahkan realisasi proses pengendalian internal. Unsur yang termasuk dalam sistem informasi dan komunikasi adalah:
a. Menggunakan informasi yang relevan.
b. Komunikasi internal.
c. Komunikasi eksternal.

5. Pemantauan adalah proses evaluasi dari pelaksanaan komponen pengendalian lainnya. Dan untuk mengarahakan organisasi untuk mencapai tujuan dan meminimalisir risiko. Unsur yang ada pada komponen pemantauan yaitu:

a. Evaluasi berkelanjutan dan/atau terpisah.

b. Mengevaluasi dan melaporkan setiap kekurangan.

Perbankan, Kredit, dan Kredit Modal Kerja. Undang-Undang No. 10 Tahun 1998 menjelaskan mengenai definisi bank yaitu badan usaha yang akan menghimpun dana dari masyarakat dalam bentuk simpanan kemudian menyalurkannya kepada masyarakat dalam rangka meningkatkan taraf hidup rakyat banyak. Menurut Undang-Undang No. 71992 kredit merupakan penyediaan tagihan dan uang yang bisa disamakan berdasarkan kesepakatan atau persetujuan pinjam meminjam antara pihak bank dengan pihak nasabah atau peminjam serta mewajibkan peminjam untuk melunasi hutangnya dengan jumlah bunga, imbalan, atau bagi hasilnya dalam jangka waktu yang telah ditentukan. Menurut Budisantoso dan Nuritomo (2014:149) Kredit Modal Kerja (KMK) adalah pembiayaan kebutuhan untuk modal kerja dari nasabah dengan memberikan kredit. Kredit Modal Kerja (KMK) itu adalah pemberian modal bagi usaha nasabah yang telah beroperasi minimal 1 tahun dan memiliki ijin usaha.

Sistem Akuntansi Pemberian Kredit Modal Kerja. Berdasarkan penjelasan mengenai sistem akuntansi di atas maka dapat didefinisikan bahwa sistem akuntansi pemberian kredit modal kerja adalah unsur-unsur pemberian kredit modal kerja yang saling berkaitan sehingga bisa berguna untuk mengolah data-data perusahaan dan menghasilkan laporan untuk digunakan oleh pihak internal dan eksternal perusahaan.

Aspek-Aspek Sistem Akuntansi Dalam Prosedur Pemberian Kredit Modal Kerja Menurut Kasmir (2012).

1. Pada tahap permohonan kredit. Pada tahap ini, calon debitur harus memenuhi beberapa prosedur dan ketentuan yang telah ditetapkan oleh bank.

2. Pada tahap analisis kredit. Pada tahap ini, akan dilakukan pemeriksaan berkas-berkas untuk mengetahui apakah berkas yang diajukan sudah lengkap sesuai persyaratan dan sudah benar. Kemudian akan dilakukan wawancara dan survey on the spot.

3. Pada tahap putusan kredit. Pada tahap putusan kredit ini biasanya yang memutuskan adalah pimpinan. Dimana pimpinan tersebut yang memberikan keputusan apakah kredit akan diberikan/diterima atau ditolak. Jika diterima maka akan dipersiapkan administrasinya dan akan dilakukan penandatangan perjanjian kredit kemudian realisasi kredit.

4. Pada tahap penyaluran atau penarikan kredit. Pada tahap ini merupakan puncak dan tahap akhir dalam pemberian kredit. Dimana setelah tahap putusan kredit jika diterima maka akan dilakukan penyaluran dana dan kemudian setelah selesai akan dilakukan penarikan sesuai dengan kesepakatan antara debitur dan kreditur. Ataupun ketika salah satu pihak tidak mampu memenuhi persyaratan saat berjalannya kredit tersebut maka akan dilakukan penarikan sesuai dengan perjanjian.

5. Pada tahap monitoring kredit. Pada tahap ini adalah tahap tambahan yang dilakukan dari pihak kreditur. Dimana pihak kreditur akan melakukan monitoring terhadap debitur selama berjalannya kredit apakah masih layak untuk dilanjutkan hingga akhir perjanjian 
kredit atau tidak. Jika tidak maka akan dilakukan penarikan dana dan denda sesuai dengan kesepakatan yang telah dibuat.

\section{METODE PENELITIAN}

Jenis dan Sumber Data. Jenis data yang akan diteliti berupa data kualitatif. Data kualitatif yang dibutuhkan dalam penelitian ini adalah Sistem Pengendalian Internal Terhadap Sistem Akuntansi Pemberian Kredit Modal Kerja pada PT. Bank SulutGo cabang pembantu Sam Ratulangi. Dan sumber data yang dalam penelitian ini adalah data primer dan data sekunder. Data primer yang dibutuhkan adalah data olahan yang diperoleh langsung dari PT. Bank SulutGo cabang pembantu Sam Ratulangi bagian kredit modal kerja dan data sekunder yang diambil dari bahan pustaka.

Metode Analisis. Metode analisis dari penelitian ini termasuk kedalam penelitian deskriptif. Metode ini adalah metode yang digunakan untuk menggambarkan atau menganalisis suatu hasil penelitian tetapi tidak digunakan untuk membuat kesimpulan yang lebih luas. (Sugiyono 2010:29).

\section{HASIL PENELITIAN DAN PEMBAHASAN}

\subsection{Hasil Penelitian}

Berdasarkan penelitian PT. Bank SulutGo Cabang Pembantu Sam Ratulangi memiliki prosedur otorisasi khususnya pada bagian kredit modal kerja yang telah diterapkan secara baik, meskipun dalam pelaksanaanya terkadang masih harus dilakukan perbaikan untuk menghindari terjadinya masalah kredit macet. Berikut ini akan dijelaskan secara rinci bagaimana hasil penelitian mengenai sistem akuntansi dalam pemberian kredit modal kerja pada Bank SulutGo Cabang Pembantu Sam Ratulangi:

1. Pada saat permohonan kredit. Pada saaat permohonan kredit pada Bank SulutGo cabang pembantu Sam Ratulangi calon debitur harus memenuhi beberapa ketentuan dan kemudian mengisi formulir dengan melampirkan berkas-berkas sesuai dengan prosedur dan ketentuan sebagaimana yang dijelaskan pada sub bab sebelumnya. Kemudian setelah syarat dan ketentuan telah dipenuhi oleh calon debitur, berkas-berkas yang ada akan diperiksa oleh bagian administrasi kredit. Dan setelah diperiksa, berkas-berkas yang telah memenuhi syarat/telah lengkap akan diserahkan kebagian operasional atau analisis kredit.

2. Pada saat analisis kredit. Tahap berikutnya setelah pengajuan permohonan kredit yaitu analisis kredit, yang akan dilakukan oleh bagian analis kredit modal kerja. Sesuai dengan hasil wawancara pada narasumber tugas yang akan dilakukan oleh analis kredit yaitu melakukan pemeriksaan kembali kelengkapan berkas-berkas dari calon debitur yang ada serta melakukan BI Checking. Kemudian setelah itu akan melakukan wawancara dengan calon debitur dan melakukan survey On the spot serta menilai agunan nasabah. Setelah melakukan survey akan dibuat laporan sesuai dengan keadaan calon debitur yang sebenarnya.

3. Pada saat putusan kredit. Pada tahap ketiga yaitu tahap putusan kredit. Dari hasil penelitian yang didapatkan lewat wawancara, tahap ini akan dilakukan oleh pimpinan cabang. Dan sebelum kredit diputuskan, pimpinan cabang bersama dengan semua petugas atau karyawan kredit yang menerima permohonan dan yang menganalisis kredit tersebut akan melakukan pembahasan serta pemeriksaan kembali. Mengenai semua data debitur dan hasil wawancara serta laporan hasil survey on the spot yang telah diterima dan dianalisis oleh petugas kredit dan analis kredit. Setelah proses pembahasan dan pemeriksaan kembali maka kemudian akan diputuskan apakah permohonan kredit tersebut diterima atau ditolak. Dan selanjutnya jika diterima/disetujui permohonan kredit modal kerja tersebut maka akan diberikan catatan hasil putusan ke bagian administrasi kredit dan akan dibuatkan formulir putusan kredit (PTK). Namun jika ditolak/tidak 
disetujui, maka akan diberikan catatan hasil putusan serta berkas-berkas yang dimasukan oleh debitur kepada bagian administrasi. Dan kemudian akan dibuatkan surat penolakan untuk diserahkan kepada debitur dan pengembalian berkas-berkas.

4. Pada saat penarikan kredit. Tahap terakhir pada pemberian kredit modal kerja pada PT. Bank SulutGo cabang pembantu Sam Ratulangi yaitu penarikan kredit, yang nantinya akan dilakukan oleh analis kredit dan dibantu oleh asisten administrasi. Penarikan ini dilakukan jika kredit yang diberikan oleh pihak Bank SulutGo cabang pembantu Sam Ratulangi sudah jatuh tempo atau terjadi kredit macet. Dan didasarkan pada bukti perjanjian yang dilakukan antara pihak PT. Bank SulutGo cabang pembantu Sam Ratulangi dengan debitur. Setelah penarikan, kemudian akan dibuat laporan hasil kredit untuk diserahkan dan ditandatangani oleh pimpinan cabang serta menjadi bukti dan arsip laporan keuangan bank SulutGo cabang pembantu Sam Ratulangi.

5. Pada saat monitoring kredit. Monitoring kredit ini dilakukan untuk mengontrol perjalanan kredit yang dilakukan oleh debitur, apakah berjalan dengan lancar atau tidak. Pada PT. Bank SulutGo cabang pembantu Sam Ratulangi yang melakukan monitoring kredit ini adalah analis kredit. Dan setiap akhir bulan dibuatkan laporan hasil monitoring kredit untuk menjadi bukti dan arsip bagi pihak bank maupun debitur. Dan laporan tersebut harus diperiksa dan ditandatangani oleh pimpinan cabang sebelum nantinya akan diberikan di kantor pusat PT. Bank SulutGo.

\subsection{Pembahasan}

Lingkungan Pengendalian. Berdasarkan hasil penelitian mengenai penerapan komponen pengendalian internal khususnya poin pertama yaitu lingkungan pengendalian pada PT. Bank SulutGo cabang pembantu Sam Ratulangi bagian/divisi kredit modal kerja telah diterapkan dengan baik. Hal tersebut terbukti dengan adanya karyawan yang teliti dalam memeriksa data nasabah, adanya pengawasan yang baik, adanya penerimaan karyawan yang berpengetahuan dan memiliki kualitas unggul serta pelaksanaan tugas sesuai dengan job description dan struktur organisasi. Dan PT. Bank SulutGo cabang pembantu Sam Ratulangi bagian/divisi kredit modal kerja juga menetapkan aturan/sanksi untuk para staf dan karyawan yang melakukan kesalahan sehingga mendukung terciptanya lingkungan pengendalian internal yang baik pula.

Penilaian Risiko. Berdasarkan hasil penelitian yang dilakukan pada PT. Bank SulutGo cabang pembantu Sam Ratulangi bagian/divisi kredit modal kerja. Penerapan komponen COSO yang kedua yaitu penilaian risiko telah dilakukan/diterapkan dengan baik. Dimana, dapat dilihat bahwa PT. Bank SulutGo cabang pembantu Sam Ratulangi bagian/divisi kredit modal kerja selalu mewaspadai akan adanya risiko-risiko yang akan dialami saat melakukan pemberian kredit modal kerja dengan menentukan tujuan yang sesuai, serta selalu belajar dan memperbaiki kesalahan-kesalahan yang terjadi untuk meminimalisir terjadi fraud/kecurangan pada saat pemberian kredit modal kerja. Dapat juga dilihat dari data yang ada tentang KAP/NPL dari PT. Bank SulutGo cabang pembantu Sam Ratulangi bagian/divisi kredit modal kerja pada tabel berikut ini diakhir tahun 2015 dan 2016 bagaimana perubahan yang terjadi membuktikan bahwa PT. Bank SulutGo selalu berusaha untuk meminimalisir terjadinya kredit macet dan berusaha untuk meningkatkan laba disetiap tahunnya.

Aktivitas Pengendalian. Untuk komponen sistem pengendalian internal yang ketiga yaitu aktivitas pengendalian berdasarkan pada hasil penelitian yang diuraikan dalam penerapannya pada PT. Bank SulutGo cabang pembantu Sam Ratulangi bagian/divisi kredit modal kerja telah diterapkan dengan baik. Dengan adanya pemilihan dan pengembangan kegiatan pengendalian, kontrol umum atas teknologi, dan merinci dalam penerapan kebijakan serta prosedur yang baik oleh PT. Bank SulutGo cabang pembantu Sam Ratulangi 
bagian/divisi kredit modal kerja sehingga dapat meminimalisir terjadinya risiko-risiko yang akan menghambat pencapaian tujuan.

Sistem Informasi dan Komunikasi. Dari hasil penelitian yang telah dilakukan dapat dilihat bahwa PT. Bank SulutGo cabang pembantu Sam Ratulangi bagian/divisi kredit modal kerja telah menerapkan komponen sistem informasi dan komunikasi dengan baik. Hal itu terbukti dengan adanya komunikasi yang baik antara semua petugas/karyawan kredit modal kerja dan juga antara petugas dengan nasabah mengenai informasi-informasi saat pemberian kredit modal kerja. Sehingga baik pihak internal maupun eksternal bisa memiliki pesan/informasi yang jelas tentang apa yang harus dan sedang dilakukan saat proses kredit modal kerja berlangsung hingga berakhir. Dan hal tersebut sangat menunjang berjalannya sistem pengendalian internal perusahaan dengan baik.

Pemantauan. Pada komponen pemantauan ini dapat dilihat sesuai dengan hasil penelitian bahwa PT. Bank SulutGo cabang pembantu Sam Ratulangi bagian/divisi kredit modal kerja telah melakukannya dengan baik. Dengan adanya evaluasi yang dilakukan setiap bulan dan laporan-laporan mengenai hasil kinerja karyawan dan proses berjalannya kredit modal kerja maka PT. Bank SulutGo cabang pembantu Sam Ratulangi telah mengusahakan proses pengendalian internal berjalan dengan baik untuk mencapai tujuan dan meminimalisir setiap risiko-risiko yang mungkin terjadi pada setiap proses pemberian kredit modal kerja yang dijalankan.

\section{KESIMPULAN DAN SARAN}

\subsection{Kesimpulan}

Berdasarkan hasil penelitian yang telah dilakukan dan pembahasan yang telah dikemukakan, maka dapat disimpulkan bahwa:

1. Lingkungan pengendalian internal pada sistem akuntansi pemberian kredit modal kerja di PT. Bank SulutGo Cabang Pembantu Sam Ratulangi telah diterapkan dengan baik untuk setiap unsur dalam komponen sistem pengendalian internal sesuai dengan standard dari COSO.

2. Penliaian risiko yang diterapkan oleh PT. Bank SulutGo Cabang Pembantu Sam Ratulangi bagian kredit modal kerja telah diterapkan dengan baik sesuai dengan setiap unsur-unsur yang didalam komponen penilaian risiko menurut COSO.

3. Untuk aktivitas pengendalian pada proses pemberian kredit modal kerja PT. Bank SulutGo Cabang Pembantu Sam Ratulangi juga diterapkan dengan baik dan sangat mempengaruhi proses pencapaian tujuan serta untuk meminimalisir risiko-risiko yang akan menghambat untuk mencapai tujuan.

4. Sistem informasi dan komunikasi yang diterapkan oleh PT. Bank SulutGo Cabang Pembantu Sam Ratulangi bagian kredit modal kerja telah baik untuk menunjang sistem pengendalian internal terhadap sistem akuntansi pemberian kredit modal kerja.

5. Dan untuk komponen sistem pengendalian internal yang terahkir yaitu pemantauan juga telah diterapkan dengan baik oleh PT. Bank SulutGo Cabang Pembantu Sam Ratulangi bagian kredit modal kerja untuk menunjang tercapainya tujuan perusahaan dan meminimalisir risiko yang akan terjadi.

\subsection{Saran}

Saran yang dapat diberikan dari peneliti:

1. Untuk PT. Bank SulutGo Cabang Pembantu Sam Ratulangi bagian kredit modal kerja kedepannya tetap mempertahankan sistem pengendalian internal yang telah diterapkan dan tetap selalu mengembangkan proses kredit modal kerja sesuai dengan perkembangan yang ada serta selalu menjaga hubungan baik dengan nasabah agar semakin banyak lagi nasabah khususnya kredit modal kerja yang ada di PT. Bank SulutGo Cabang Pembantu Sam Ratulangi. 
2. Lebih memperketat prosedur dan ketentuan pemberian kredit modal kerja serta jaminanjaminan yang akan diberikan saat proses kredit modal kerja untuk semakin meminimalisir terjadinya kredit macet yang akan dilakukan oleh nasabah nantinya.

3. Dan untuk seluruh petugas-petugas kredit modal kerja tetap mempertahankan sistem kerja yang telah dilakukan agar PT. Bank SulutGo Cabang Pembantu Sam Ratulangi bagian kredit modal kerja kedepannya semakin maju, berkembangan, dan mendapatkan keuntungan yang lebih besar.

\section{DAFTAR PUSTAKA}

Baridwan, Zaki. 2012. Sistem Akuntansi Penyusunan Prosedur dan Metode Edisi Kelima. Yogyakarta: BPFE.

Budisantoso. Totok. dan Nuritomo. 2014. Bank Dan Lembaga Keuangan Lain Edisi 3. Jakarta Salemba Empat.

COSO. 2013. Internal Control-Integrated Framework: Executive Summary. Durham. North Carolina

Kasmir. 2012. Bank dan Lembaga Keuangan Lainnya. PT Raja Grafindo Persada. Jakarta.

Krismiaji. 2015. Sistem Informasi Akuntansi. Edisis Keempat. Sekolah Tinggi Ilmu Manajemen YPKN. Yogyakarta

Mulyadi. 2016. Sistem Akuntansi. Jakarta: Salemba Empat

Otinur, Fauzan. Pangemanan, Sifrid. dan Warongan, Jessy. 2017. Analisis Sistem Informasi Akuntansi dan Sistem Pengendalian Internal Persediaan Barang Pada Toko Campladean Manado. Jurnal Riset Akuntansi Going Concern 12(1), 2017. Halaman 169179. Universitas Sam Ratulangi Sulawesi Utara

Permatasari, Desi. 2016 Analisis Sistem Akuntansi Pemberian Kredit Modal Kerja Dalam Upaya Meningkatkan Pengendalian Manajemen Kredit (Studi Kasus pada PT. Bank Pembangunan Daerah Jawa Timur, Tbk Cabang Nganjuk. Jurnal Administrasi Bisnis. Volume 33. No. 2, April 2016. Universitas Brawijaya

Pontoh, Winston. 2013. Akuntansi Konsep Dan Aplikasi. Jakarta Barat: Halaman Moeka

Prastiwi, Destiana. 2017. Analisis Pengendalian Internal Sistem Pemberian Kredit Berbasis COSO Studi Kasus di BPR Chandra Muktiartha. Skripsi. Fakultas Ekonomi. Universitas Sanata Dharma Yogyakarta

Undang-Undang Republik Indonesia Nomor 7 Tahun 1992 Perbankan. 25 Maret 1992.

Walter. Horngren. dan Suwardy. 2013. Akuntansi Keuangan. Edisi IFRS. Edisi Kedelapan. Jilid 2. Erlangga. Jakarta. 